with corneal change where-no silver preparation was used, while the process involving the cornea in the eye where no treatment sheet could be found, resulted in a blind eye.

Standish $^{3}$ reports 32 cases treated with protargol with corneal involvement in 34 per cent. and 23 cases treated with argyrol with subsequent corneal changes in 30.5 per cent. He rcports ${ }^{4}$ an additional 29 cases treated with argyrol, so that in all he had treated 52 cases with this preparation with subsequent corneal involvement in 22 cases, or 42 per cent.

Standish, since the appearance of argyrol, has given the preparation a thorough trial and evidently still regards it as our best method of exhibiting silver in gonococcus infections of the conjunctiva, despite Derby's most interesting paper on the bactericidal properties of the various silver preparations now on the market. Derby, ${ }^{5}$ in his laboratory experiments, used the Staphylococcus pyogenes aureus instead of the gonococcus owing to the difficulties attending the propagation of the latter by our present laboratory methods. He found that nitrate of silver in 0.5 per cent. to 2 per cent. solutions killed the culture in 2 to 5 minutes and that an exposure of 30 scconds to a 0.5 per cent. solution was sufficient to prevent its growth. Protargol in from 2 per cent. to 4 per cent. solutions lilled in from 3 to $5 \mathrm{~min}$ utes, while a one-minute exposure prevented growth. Collargol in a 4 per cent. solution failed to prevent a growth after an exposure of an hour. Ichthargan and argentamin in weak solutions both killed the growth after an exposure of 4 minutes, but he adds that both are very irritating.

He states that argyrol's bactericidal properties are very weak and that a large series of observations gave a growth after an exposure of 1 to 2 hours to solutions the strength of which varied from 10 per cent. to 50 per cent. He calls attention to the experiments of Verhoeff and confirms his statements that if human blood serum be added to solutions of sodium aurate and protargol their bactericidal properties are destroyed. $\mathrm{He}$ also states that he found that the action of Lugol's solution and bichlorid solution of the strength of $1: 1000$ was much retarded by serum such as hydrocele fluid and bovine blood serum.

Group 2.-Conjunctivitis Neonatorum. Here I deem it necessary again to refer to the general nutrition of the majority of the cases that come under observation in the Philadelphia General Hospital, a factor which has no little bearing on the ocular results in these cases.

Inasmuch as the vast majority of these infants come from the lowest social strata in the city, poverty, ignorance and negligence are responsible for the advanced stages of malnutrition so frequently seen on their admission and renders a prognosis grave, not only from an ocular aspect, but from a systemic one as well.

In taking up the cases in this group we find that cold was used in the initial stages in the majority of cases, but not as consistently as in Group 1. For cleansing, boric acid was used in 36 cases, potassium permanganate in 14, formalin in 5 and bichlorid in 2 cases. Here, as in Group 1, sterile water and physiologic salt solution were used with the above in some cases.

THE SILPER SALTS IN CONJUNCTIVITIS NEONATORUM.

As to silver, the nitrate was used in 32 cases, argyrol in 8 , nitrate of silver and argyrol in 9 , the nitrate and

4. Ophthalmic Record, August, 1906

5. Boston Med. and Surg. Jour., Sept. 27, 1906. protargol in 1 and no silver preparation in 7 cases. It is interesting to note the result in this last group, for these 7 cases treated without any silver preparation recovered with the cornea intact or at least no note of any lesion could be found on the records. Whether the result obtained in these few cases was influenced by the less amount of manipulation required, by the character of the infection or by the few cases reported, can not be determined, but probably all were contributing factors.

Referring again to those instances in which the eye was free from corneal involvement on admission, we find that 50 of these eyes were treated with nitrate of silver, with subsequent corneal involvement in 6 , or 12 per cent; 14 eyes were treated with argyrol, in which but 1 developed corneal changes, or 7.14 per cent.; 16 with nitrate of silver and argyrol, with 2 showing corncal changes, or 12.5 per cent.; 2 with nitrate of silver and protargol, in both of which the cornea became involved, while in 13 eyes no silver preparation was used and, as above stated, none of these developed abnormalities of the cornea. Standish reports 50 cases treated with nitrate of silver with corneal involvement in 5.6 per cent.; 150 cases trcated with protargol, with corneal changes in 2 per cent., and 201 cases with argyrol in which only 4 cases, or 2 per cent., developed some corneal abnormality.

In the 11 eyes that developed some change in the corneal structure while under observation, the treatment was as follows: With nitrate of silver one eye was blind or had but light perception, while in 5 there were varying degrees or no visual impairment. This gives a total loss of vision in 2 per cent. of the eyes so treated.

With argyrol one eye became blind or a total loss of vision in 7.14 per cent. In the 2 eyes with corneal involvement treated with nitrate of silver and argyrol, neither resulted in a destruction of vision, while in the 2 treated with nitrate of silver and protargol the corneal changes were extensive and produced blind eyes.

In conclusion, it may be noted that at Blockley both the Credé method and the instillation of argyrol are used at the maternity. At the University maternity, argyrol has been consistently used during the past year or two, while at the Preston Retreat I have been told that argyrol was abandoned about one year ago and that the Credé method is now exclusively employed. At the Maternity Hospital the Credé method alone is used. 1928 Chestnut Street.

\section{A CONTRIBUTION TO THE STUDY OF THE OPSONINS.}

\section{ERNEST A. KNORR, M.D.} BAITIMORE.

While engaged in the study of the opsonins there arose the following questions which have not received appropriate consideration in previous publications and which, nevertheless, are deemed important:

1. What influence has the strength of the bacterial emulsion on the phagocytic index and the percentage of phagocyting cells?

To this end an emulsion of the Staphylococcus aureus of definite strength was prepared and progressively diluted; the serum and corpuscles came from a healthy individual. The resuits are shown in Table 1.

In this table it will be observed that the phagocytic index and the percentage of phagocyting cells are, generally speaking, in direct proportion to the strength of the bacterial emulsion. This influence of the varying 


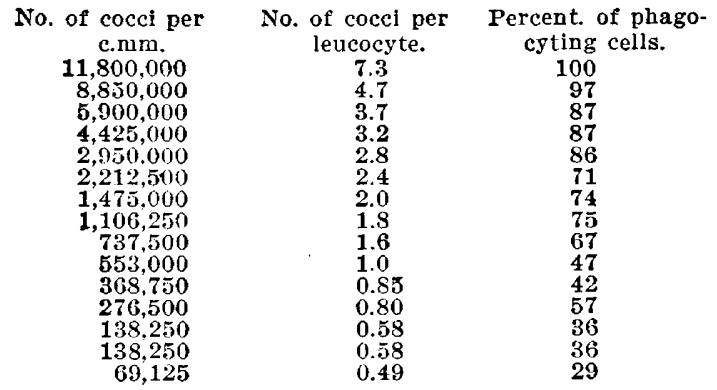

strength of the emulsion is further shown in Table 2 , in which both the opsonic bacillary index (Wright) and the percentage index (Simon) are worked out:

TABLE 2.

\begin{tabular}{|c|c|c|c|c|c|c|}
\hline \multirow[t]{2}{*}{$\begin{array}{l}\text { No. of coeci } \\
\text { per c.mm. }\end{array}$} & \multicolumn{2}{|c|}{$\begin{array}{l}\text { No. of cocel per } \\
\text { leucocyte } \\
\text { Patient's }\end{array}$} & \multicolumn{2}{|c|}{$\begin{array}{l}\text { Percent. of pha- } \\
\text { gocyting cells. } \\
\text { Patient's }\end{array}$} & \multirow[t]{2}{*}{$\begin{array}{l}\text { Wright's } \\
\text { index. }\end{array}$} & $\begin{array}{l}\text { Simon's } \\
\text { index. }\end{array}$ \\
\hline & serum. & Pool. & serum. & Pool. & & \\
\hline $3,750,000$ & 2.54 & 3.15 & 87 & 82 & & 0.94 \\
\hline $1,87 \overline{5}, 0$ & 1.68 & 1.9 & 68 & 70 & & 0.85 \\
\hline $\begin{array}{l}937,5 \\
468.7\end{array}$ & $\begin{array}{l}1.26 \\
1.02\end{array}$ & 1.3 & 58 & $\begin{array}{l}65 \\
45\end{array}$ & $\begin{array}{l}0.90 \\
1.30\end{array}$ & 0.89 \\
\hline $\begin{array}{l}468,750 \\
234,375\end{array}$ & $\begin{array}{l}1.02 \\
0.73\end{array}$ & $\begin{array}{l}1.78 \\
0.71\end{array}$ & $\begin{array}{l}30 \\
37\end{array}$ & 33 & $\begin{array}{l}1.30 \\
1.02\end{array}$ & 1.05 \\
\hline
\end{tabular}

2. What effect has the period of incubation on phagocytosis? To determine this point charged pipettes were incubated for varying periods of time at $39 \mathrm{C}$. The phagocytic index and the percentage of phagocyting cells were then determined as usual. The strength of the bacterial emulsion corresponded to 937,500 cocci per c.mm.

$\begin{array}{cc}\text { TABLE } 3 . & \\ \text { No. of cocci per } & \text { Percent. of phago- } \\ \text { leucocyte. } & \text { cyting cells. } \\ 1.36 & 65 \\ 2.24 & 65 \\ 2.80 & 87 \\ 4.00 & 90 \\ 4.01 & 90\end{array}$

The results show that with a long exposure both the phagocytic index and the percentage of phagocyting cells undergo a distinct increase, the maximum being reached in one hour. After two hours the degenerative changes in the leucocytes become so extensive that accurate observations are rendered impossible.

3. Does phagocytosis occur at room temperature, viz., from 13 to $15 \mathrm{C}$.? Pipettes were chirged as usual and left for varying periods of time as indicated in Table 4 .

$\begin{array}{ccc} & \text { TABLE } 4 . & \\ \text { No. of cocei per } & \text { Percent. of phago- } \\ \text { Period of exposure. } & \text { leucocyte. } & \text { cyting cells. } \\ \text { One hour. } & 0.18 & 14 \\ \text { Two bours. } & 0.76 & 35 \\ \text { Three hours. } & 0.89 & 36 \\ \text { Six hours. } & \mathbf{1 . 2 2} & \mathbf{4 7}\end{array}$

This shows that phagocytosis does occur, but that an exposure of fully six hours is necessary before the extent of phagocytosis reaches those figures which we usually see after fifteen minutes exposure at body temperature.

4. What effect has the number of persons composing the pool on the opsonic index? In determining the above question the sera of ten healthy persons were collected and mixed in equal proportions, thus giving ten pools, containing from one to ten sera. With these the opsonic index was determined, using an emulsion of the Staphylococcus aureus. The normal serum gave 56 per cent. of phagocyting cells, with an average number of cocci per leucocyte of 1.14 .

'Table 4 shows plainly the advantages of Simon's percentage index over Wright's bacillary index, which latter will vary to a greater extent if cells are included in the count in which maximal numbers of organisms are contained, which is frequently almost unavoidable, owing to the difficulties which attend the preparation of perfectly homogenous emulsions. With specially satisfactory emulsions the two indices practically coincide. It is apparent that Simon's index is thus a check on the bacillary index.

TABLE 5.

\begin{tabular}{|c|c|c|c|c|}
\hline \multicolumn{2}{|c|}{ Percent. of phago- } & No. cocel per & Wright's & Simon's \\
\hline Pool. & cyting cells. & leucocyte. & index. & index. \\
\hline ne person . & $\ldots 62$ & 1.24 & 0.91 & 0.90 \\
\hline wo persons. & $\ldots$ & 1.18 & 0.96 & 0.98 \\
\hline Three persons & is.. & 1.42 & & \\
\hline Four persons & $\ldots$ & 1.16 & 0.9 & 1.00 \\
\hline ive persons. & $\ldots$ & 1.19 & 0.8 & 0.87 \\
\hline ix persons. & $\ldots$ & 1.52 & 0.75 & 0.79 \\
\hline ven persons & as. . & & & 0.96 \\
\hline ight persons & S... & 1.40 & 0.8 & 0.93 \\
\hline e persons & $\ldots$ & 1. & & 0.82 \\
\hline & & 1.52 & & \\
\hline
\end{tabular}

If we interpret the finding in Table 5 in this sense, the variations in Wright's index are readily explained, and it follows that a simple or at most a double mixed pool is necessary for ordinary purposes, a conclusion to which I believe Wright himself has come.

5. What effect has the age of the culture on phagocytosis? An emulsion (a) was made from a 46-hours-old culture containing $2,350,000$ cocci per c.mm., and a second emulsion (b) from a 42-days growth containing $3,380,000$ cocci per c.mm. In the first instance the average number of cocci per leucocyte was 4.84 and the percentage of phagocyting cells 95 , while in the second case the phagocytic index was 9.6 and the percentage of phagocyting cells 99 . It follows that the aging of the culture does not lead to a drop in the phagocytic or percentage index.

6. What effect has boiling and the addition of preservatives to bacterial emulsions on phagocytosis? The above emulsion (a) was placed in boiling water for 30 minutes, after which the phagocytic index was 7.18 and the percentage of phagocyting cells 96 . This heated culture was then preserved for 3 days with about 0.25 per cent. of lysol. The average number of cocci per leucocyte was now 2.81 and the percentage of phagocyting cells $7 \%$.

One portion of emulsion (b) was similarly preserved with thymol and the remainder with chloroform for 3 days. In the first instance the phagocytic index was 8.03 and the percentage of phagocyting cells 95 , and in the second 8.43 and 98 respectively.

This shows that boiling, thymol and chloroform have no inhibitory effect on the opsonic values, so far as the usual technic goes, while lysol seems to produce a decrease.

7. How long do the opsonins remain active? In other words, how long can the serum be kept before examination using the small quantities which are usually taken?

The results show that the serum loses one-half of its opsonic power in 24 hours; after this there is practically no further loss in the following 24 hours. The value then rapidly drops, but, however, does not wholly disappear until after 5 days. It is to be noted that the serum was collected and kept in a sterile condition. (Table 6.)

How long do the corpuscles retain their capacity for

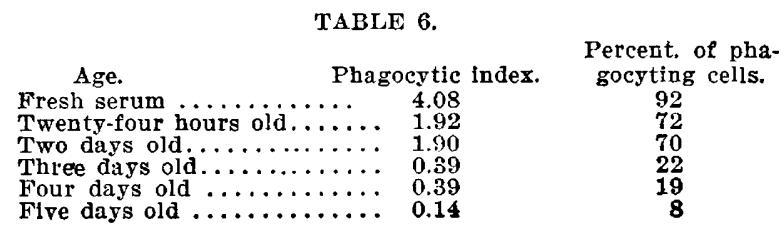


phagocytosis? In this instance also the corpuscles were kept sterile and fresh serum used in every case. (Table \%.)

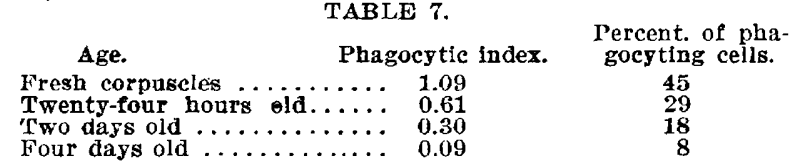

The results show that only fresh corpuscles can be used in opsonic work, and my experience has been that after six hours many of the cells are dead and that fallacious results are obtained if such cells are used.

9. How many cells must be counted in order to obtain a satisfactory result? Emulsions of various strengths were prepared, and both the bacillary and Simon's index determined for $25,50,75,100,150,200,300$ and 400 cells respectively. The results are shown in Table 8.

TABLE 8.

A. Emulsion of 2,000,000 cocci per c.mm.: Cells counted. Wright's index.

25
50
75
100
150
200
300

1.00
0.97
0.96
1.69
1.16
1.23
1.18

B. Emulsion of 666,666 cocci per c.mm. :

Cells counted. Wright's index.

$\begin{array}{rr}25 & 1.85 \\ 50 & 1.32 \\ 75 & 1.03 \\ 100 & 1.25 \\ 150 & 1.30 \\ 200 & 1.12 \\ 300 & 1.13\end{array}$

400

C.Emulstion of 222,222 coccl per c.mm.

Cells counted. Wright's index.

$\begin{array}{rl}25 & 1.2 \\ 50 & 1.6 \\ 75 & 1.7 \\ 100 & 1.7 \\ 150 & 2.2 \\ 200 & 2.15 \\ 300 & 2.00\end{array}$

D. Emulsion of 74,074 cocci per c.mm. :

Cells counted. Wright's index.

$\begin{array}{lcc}25 & \text { No index. } & \text { No fndex. } \\ 50 & 0.66 & 1.00 \\ 75 & 0.50 & 0.62 \\ 100 & 0.57 & 0.70 \\ 150 & 1.14 & 1.26 \\ 200 & 1.18 & 1.15 \\ 300 & 0.95 & 0.96 \\ 400 & 1.05 & 1.11\end{array}$

The results show that with weak emulsions the chances of error are greater than with stronger emulsions, bearing in mind that with too rich emulsions counting becomes difficult, if not impossible.

In these experiments, likewise, the advantage of Simon's index is at once apparent, although with the weaker emulsions it also becomes somewhat uncertain.

In conclusion I wish to express my appreciation to Dr. Charles E. Simon, at whose suggestion the above experiments were undertaken.

1727 West Lombard Street.

Induced Hyperemia in Treatment of Acute Infections.G. Fichera publishes in the Policlinico, xiv, 6, 1907, the results of extensive experimental and clinical research on the efficacy and the mechanism of Bier's stasis hyperemia. His article is illustrated and is accompanied by nearly 8 pages of international bibliography on the subject. His conclusions are to the effect that the hyperemia induced retards the circulation through the part, while the transudation and diapedesis impede the general invasion of the organism by the bacilli. At the same time as the medium becomes less favorable for them, they fall a prey to the migrating leucocytes as phagocytosis is exceptionally active under these conditions.

\section{GONORRHEAL PROSTATITIS.* \\ J. BAYARD CLARK, M.D. \\ NEW YOBK CITY.}

The constancy with which prostatitis occurs when gonorrhea invades the posterior urethra, and the persistent nature of that inflammation after the subjective symptoms, and the more evident of the objective symptoms, have subsided, give this condition the right to more consideration.

That a gonorrheal inflammation of the posterior urethra ever occurs without involving the prostatic ducts to a greater or less degree seems unlikely. Anatomically, there is little to invite a posterior urethritis to the exclusion of the prostate. The character of the epithelia, the scarcity of mucous glands, and the almost vertical direction of the canal, which is distended so much of the time with urine and made one with the bladder cavity, are factors against a theory that the prostatic urethra can be affected with a gonorrheal infection without the prostate participating.

Acute gonorrheal prostatitis-the division of this affection into the catarrhal, the follicular, and the parenchymatous forms-may well be accepted as expressing the clinical varieties, providing the tendency of one form to merge into another is appreciated.

\section{CATARRHAL PROSTATITIS.}

This form is by far the most frequent of the acute varieties. It is highly probable that with every posterior gonorrhea there is some involvement of the prostate and though it may extend but a short distance into the prostatic ducts and be relatively mild, it is obvious that its existence should be appreciated.

The symptoms of catarrhal prostatitis go hand in hand with the symptoms of posterior urethritis-the increased desire to urinate, the cloudiness of both portions of urine, and the characteristic small, round and commashaped shreds which so often appear. These filaments, when examined microscopically, are usually small plugs or casts made up of mucus, pus cells, cuboidal and cylin. drical epithelia, and gonococci. The prostatic origin of these shreds is not difficult to prove. If after a portion of the urine is voided light digital pressure is made on the prostate, the shreds are squeezed into the urethra and carried out with the urine which is then passed.

The danger of manipulating the prostate during an acute inflammation of that organ is ever to be borne in mind on account of its tendency to produce not only an acute epididymitis but an extension of the prostatic involvement as well. The clearing up of the acute posterior urethritis is, I believe, seldom accompanied with a resolution of the catarrhal prostatitis. Its tendency is to go on to a chronic condition.

The diagnosis must usually be made by the urine, as examination of the gland by the rectum frequently fails to show any change in size or consistence or give any areas of tejiderness.

\section{FOLLICULAR PROSTATITIS.}

This may be an extension of the catarrhal form or it may follow directly the onset of an acute urethritis posterior. The process of inflammation extends in a selective way along certain ducts toward the periphery of the gland, and usually in its upper part, there to establish, by purulent or cystic distension of the alveoli, the small nodules or tender areas detected by digital exami-

* Read before the Section on Genito-Urinary Diseases of the New York Academy of Medicine, November 21, 1906. 